\title{
Theatre and Sea Turtles: An Intervention in Biodiversity Education
}

\author{
Emel Okur-Berberoglu \\ LIC (Livestock Improvement Corporation), 140 Riverlea Road, Hamilton, New Zealand. \\ E-mail: emelokur17@gmail.com (Corresponding author) \\ Sukran Yalcin- Ozdilek \\ Canakkale Onsekiz Mart University, Science and Art Faculty, Department of Biology \\ Terzioglu Campus, 17100 Canakkale-Turkey, E-mail: syalcinozdilek@ gmail.com
}

\section{Bektas Sonmez}

Cumhuriyet University, Suşehri Timur Karabal Meslek Yuksek Okulu, E-mail: bsonmez@cumhuriyet.edu.tr

\section{Ozlem Sila Olgun}

Ministry of Environment and Forestry, Department of Environmental Services, Turkey, E-mail: osolgun@ormansu.gov.tr

\begin{abstract}
Biodiversity is an important part of the ecology and sustainable development. Turkey is a developing country and sustainable development is difficult for Turkey because of adopting Mickey Mouse economic development model. In other words, the economic development is in front of the sustainable development. However, Turkey has biodiversity richness so rural people's biodiversity education is especially so important. One of this richness is seat turtles ( $C$. mydas and $C$. caretta). Hatay, Samandag beaches are important nesting areas for these sea turtles so research groups of this study are from Samandag. There were two groups (experimental and control), and 206 6th grade student in this study. The aim of this study is to determine the increasing knowledge level of the students about the sea turtles life and the conservation ways of them. A theatre performance was used as an intervention. The quantitative approach was adopted in order to develop a knowledge test. We reached two results in this study: (1) The theatre method is effective in order to gain knowledge about sea turtles, (2) the theatre method is more successful than lecturing on increasing knowledge level of students about sea turtles.
\end{abstract}

Key words: theatre, sea turtles, biodiversity education, Hatay, Samandag beaches, Turkey 


\section{Introduction}

Urban population increases swiftly because of the migration of most of the people to the cities. According to UN Compendium of Human Settlements Statistics (2001), half of the world population reside in the cities. As a consequence, people have less contact with their natural environment, and cannot realize that environmental damages cause varied pollution forms, and deterioration of the life quality. For instance, the global warming is effective on shortage of the drinkable water, melting of Arctic polar, reduction of the biodiversity on the lands and oceans, and these effects are increasing day by day. One of the problems at this point is that people cannot see that all these issues are interconnected. (Sarabhai, 2011; Dervisoglu, Menzel, Soran, \& Bogeholz, 2009; Dervisoglu, 2007; Kassas, 2002a; Barker \& Elliot, 2000; Agenda 21, UN, 1992) For example the biodiversity is affected by the global climate change, marine pollution, air pollution, use of the pesticides and herbicides, forest destruction, intensive agricultural applications, etc. (Agenda 21, UN, 1992) and international foundations (IUCN, WWF, FAO, UNEP ${ }^{1}$ ) warns the governments in order to protect their biological diversities (Kassas, 2002b).

Biodiversity is one of the conspicuous subjects in the world last three decades. The generally accepted definition of biodiversity is that all species (plants, animals, microorganisms) which live in a specific area (Cepel, 2008; Kassas, 2002a). Three diversity concepts come up in terms of this definition: genetic, species, and ecosystem diversities (Cepel, 2008; Kassas, 2002a). Kassas, (2002b) especially emphasizes that there are gaps in knowledge about biodiversity. For instance, the known species on the world are very limited; most of the people do not know the role of these species (especially fungi, protozoa, algae etc), why people have to protect them, and what human effects on them are. As mentioned above environmental and ecological behaviour problems literally affect these diversities and all these problems happen in Turkey, as well.

Turkey, one of the members of G-20, is a developing country (UN, 2009), and adopts the Mickey Mouse economic model (SANZ, 2009). In other words, the economic development is in front of the sustainable development. However, Turkey has biodiversity richness among European and Middle Eastern countries because Anatolia has a special geographical location, and is like a bridge between continents (Cepel, 2008; Baskent, Kose, Terzioglu, Baskaya, \& Altun, 2005; Erten, 2004). This special location gives rise to ecosystem diversity, eventually genetic and species richness. At this point, the sustainable development and economic development of Turkey are a big dilemma because it is quite difficult to manage sustainable economic development without missing biodiversity. But it is not impossible so the biodiversity education is very important for Turkey and the world (Kilic \& Dervisoglu, 2013; Kilic, Dervisoglu, \& Kasap, 2012; Okur, Yalcin-Ozdilek, \& Sahin, 2011; Sarabhai, 2011; Uzun, Ozsoy, \& Keles, 2010; Dervisoglu et al, 2009; Dervisoglu, 2007; Erten, 2004; Kassas, 2002a; Kassas, 2002b; Young, 2001; Agenda 21 [15.10.b] UN, 1992).

\footnotetext{
${ }^{1}$ International Union for Conservation of Nature (IUCN), The World Wide Fund for Nature (WWF), The Food and Agriculture Organization of the United Nations (FAO), The United Nations Environment Programme (UNEP)
} 


\section{Literature review}

There are many more studies related to biodiversity education in the world (Saito, 2013; Menzel \& Bogeholz, 2010; Young, 2001; Gayford, 2000). In this scope, this study is limited within Turkish researches because the biodiversity education researches are very limited in Turkey, and is gaining acceleration at the last decade but there are still deficiencies. Turkish and the other countries' studies are tried to explain together within similarities and differences. Erten (2004) mentioned the biodiversity and the importance of biodiversity education for Turkey at the theoretical level. Saito (2013) explained the importance of biodiversity education within the ecological literacy and Brazil at the theoretical level, as well.

Dervisoglu et al, (2009) checked over the effects of values, beliefs and problem perception on personal norms for biodiversity protection. The study was based on the ValueBelief-Norm Theory, and there were 499 Turkish secondary school students in the study. The data was collected by the scales. According to regression analysis, the universalism only had an effect on personal norms.

Responsibility for protection of biodiversity was a predictor for the personal norms. The researchers offered that (a) the interdisciplinary perspective should be adopted for the biodiversity education program so the teacher education should be supported; (b) the norms were internalized in younger ages so the biodiversity education should be started as soon as earlier; (c) the student as a consumer should be aware of the short term/ long term effects of individual behavioural on biodiversity. Menzel and Bogeholz (2010) used same theory, similar study, and similar aim with secondary schools students but they also compared the two countries' (Chile and Germany) results.

Uzun et al. (2010) researched pro-knowledge level of the pre-service teachers about biodiversity. They used mixed methodology. The results showed that pre-service teachers knew 74 different concepts related to the biodiversity but they could only contact among 22 concepts. It meant that the pre-service teachers had limited knowledge about biodiversity and they mostly mentioned species diversity, climatic, and geographical properties of the species. The researchers pointed out that the secondary school geography education was very didactic so the students probably mentioned the geographic properties of the species. The researchers offered that the biodiversity concept and the importance of the biodiversity were especially mentioned at the tertiary level and the teacher education.

Okur et al. (2011) examined the most used methods and techniques by the primary school teachers in Canakkale (Turkey) when they taught the biodiversity concept. The data was collected by a survey. They found that the teachers mostly used traditional methods (lecturing, answer-question, and discussion) while they taught the biodiversity. The researchers offered that the active learning methods should be used but firstly, the teachers should have professional development education for the active learning methods or how they teach the biodiversity concept. Okur et al. (2011) found similar results with Gayford (2000)'s study. Gayford (2000) evaluated the perception of the science teachers about biodiversity education in the United Kingdom (UK). He found that the programs included many essential knowledge for the biodiversity education but there was little attempt to understand the 
interrelationship of the complex issues. The science teachers did not feel adequate to teach the complex environmental issues, and they offered that some active learning methods - for example role play, discussion groups, free-writing activities, storytelling, critical reading exercises, dramatic interpretations- should be used in biodiversity education.

Celikkol and Soran (2012) researched about the biodiversity knowledge levels of the secondary school students $(9,10,11$, and 12). They used the quantitative approach, and found that the knowledge level of $9^{\text {th }}$ grade was higher than the others because the biodiversity concept was started to mention at the $9^{\text {th }}$ grade syllabus.

Kilic et al. (2012) examined the individual and group proficiency of the university students on the tendency of the biodiversity protection. The data was collected by a scale. They found that there was a positive correlation between individual and group proficiency and the tendency of biodiversity education. The researchers offered that the importance of biodiversity, the effects of individual behaviour on biodiversity, the importance of taking active role with non-governmental organizations should be taught in education system. Lindemann-Matthies, Constantinou, Junge, Kohler, Mayer, Nagel, Raper, Schule, \& KadjiBeltran (2009) and Lindemann-Matthies, Constantinou, Lehnert, Nagel, Raper, \& KadjiBeltran (2011) studied with the pre-service teachers and found similar results with Kilic et al. (2012) and Okur et al. (2011). The researchers compared the teacher education program of four Europe countries (Cyprus, England, Switzerland, and Germany) within the biodiversity education. They said that the pre-service teachers could apply what they have learnt so if the biodiversity education focuses on interdisciplinary perspective and outdoor applications then the biodiversity education would be more successful in the schools.

Kilic and Dervisoglu (2013) studied about the biodiversity knowledge, pedagogical content knowledge, attitudes and concerns of the pre-service biology teachers. They used the qualitative approach and found that the pre-service teachers were not aware of the place of biodiversity in the biology curricula and instructional strategies. They had either positive attitude or concerns about teaching biodiversity. The researchers offered the redesigning of the biodiversity curriculum in teacher education.

We think that biodiversity concept can also be explained by specific subjects and as placed-based. For instance, Tankus and Soran (2012) only examined the importance of biodiversity within the wetland. They used a survey and studied with the secondary school students. They found that the students would like to protect the wetlands but they did not know how to behave. Ceken and Ayas (2010) pointed out that the science and technology subjects could be taught as place-based.

However, all these researches mention the informal or outdoor education applications but they are usually based on quantitative survey method (Kilic \& Dervisoglu, 2013; Celikkol \& Soran, 2012; Kilic et al., 2012; Tankus \& Soran, 2012; Okur et al., 2011; Dervisoglu et al, 2009), and there is no informal or outdoor application. Whereas Kassas (2002a) suggested that the outdoor and informal education beside the school curriculum should be used for the biodiversity education. There are three focus groups in these studies: secondary school 
students (Celikkol \& Soran, 2012; Tankus \& Soran, 2012; Dervisoglu et al, 2009), pre-service teachers (Kilic \& Dervisoglu, 2013; Kilic et al., 2012; Uzun et al., 2010), and in-service teachers (Okur et al., 2011).

There are three differences of this study than the other Turkish researches:

a. The study is place-based and based on the sea turtles [Chelonia mydas (L., 1758] and Caretta caretta (L., 1758)] which are endangered species. The study area is Samandag beach, Hatay.

b. The target group is the $6^{\text {th }}$ grade middle school students.

c. There is outdoor education application and the theatre is used an educational method.

These three differences are checked over by different studies in the world. For instance, Hawkey (2001) studied with 7-14 years old students and used a web-based learning material. The aim of his study was to get biodiversity knowledge and awareness of the students. This material was about the specific properties of 'woodlice' in the UK, their habitat properties, and distribution in the UK. He used the woodlice because it was very common in the UK. The web-based material was used within the National History Museum. He applied a survey to the students and found the increasing of the students' biodiversity knowledge and awareness level. Barker and Elliott (2000) tried to improve the biodiversity knowledge and awareness level of the primary and secondary school students in Bulgaria. They used some active learning methods (creative writing, role play, poster design, etc.). The research context was the biodiversity of Bulgaria but they especially mentioned the white stork because the Bulgaria was on the migration way of the white storks. The aim of this study is to determine the increasing knowledge level of the students about the sea turtles' (C. mydas and C. caretta) life and the conservation ways of them.

\section{Methodology}

Why sea turtles?

The population of the sea turtles on the world has been decreasing over the last 30 years. Much of this reduction of the sea turtle population can be thought to the shrimping industry (Eckert, 1995). The five sea turtles - the loggerhead (Caretta caretta), hawksbill (Eretmochelys imbricata), green (Chelonia mydas), Kemp's ridley (Lepidochelys kempi), and leatherback (Dermochelys coriacea)- are listed as endangered species on Conservation on International Trade in Endangered Species (CITES), Environmental Species Act (ESA) and World Conservation Union (Hilton \& Taylor, 2000). Also Hilton and Taylor (2000) report that according to IUCN criteria, $C$. mydas and $C$. caretta are endangered species. ESA (2013: 1) defines the endangered species as 'a species is in danger of extinction throughout all or a significant portion of its range.'

Turkey is a nesting habitat of $C$. mydas and $C$. caretta. Some of these two sea turtles' nesting habitats are Florida beaches of USA (Anthworth, Pike, \& Siner, 2006; Weishampel, 
Bagley, Ehrhart, \& Rodenbeck 2003; Ehrhart \& Raymond, 1983), Cyprus beaches (Ilgaz, 1998; Broderick \& Godley, 1996), Praia do Forte beaches of Brazil (Marcovaldi \& Laurent, 1996), Tortugueo beaches of Costa Rico (Campbell, Lagueux, \& Mortimer, 1996; Bjorndal, Carr, Meylan, \& Mortimer, 1985; Carr \& Carr, 1972), and some of Turkey's beaches (YalcinOzdilek \& Sonmez, 2006; Ergene, Aymak, \& Uçar, 2005; Canbolat, 2004; Canbolat, 1996; Kaska, 1993).

Samandag beaches of Hatay City are one of the important nesting habitat of C. mydas and $C$. caretta on Turkey at Mediterranean. The nesting habitats of $C$. mydas and $C$. caretta have been studied biologically (nest and nesting success, and sex ratios of hatchlings) and physically (nest moisture and temperature) (Yalcin- Ozdilek \& Sonmez, 2006). Within this research, Samandag beaches are used for some of educational activities in the 2004- 2005 spring- summer period.

\section{Why theatre method?}

The idea of using a theatre performance in education reaches to 1960s (O'Farrell, 2002; Rosenberg, 1973). The researchers point out that the theatre is a communication tool and helps people to analyse and interpret the society (Rudman, 1972; Hopkins 1963; Lippman, 1951). An effective theatre awakens the audience to have a new understanding of them, a new awareness of the world. Hence, the theatre is actually a learning area and can be used in education (Rosenderg, 1973; Rudman, 1972).

O'Farrell in his study (2002) explained the performing of varied theatre groups in England and Canada. There were usually actor-teachers in these groups but O'Farrell (2002) mentioned some groups which had young people or post-graduate people who performed for child audiences. For instance one of these groups performed a theatre related to mythical characters that lived under the ocean and they brought up against that their lives were threatened by an oil drum containing radioactive waste. However, O'Farrell (2002) did not mention any educational evaluation or research for the performance.

Nwadigwe (2007) used theatre within conservation and biodiversity education for the migrant fishermen in Nigeria. However, the fishermen acted in this study. She collected data by focus groups and individual interviews. She found that the fishermen realized how they affected on the coastal area and marine life.

Peleg and Baram- Tsabari (2011) used the theatre as an intervention and two people tried to explain some physic concepts by the theatre to the primary school children in Israel. They used mixed methodology and found that the students' knowledge level about 'atom' was increased but there was no difference on attitude.

Theatre was also used for AIDS education (Elliott, Gruer, Farrow, Henderson \& Cowan, 1996), self- reflection, and raising individual awareness of the immigrant children (Sextou, 2006), teacher education (Souto- Manning, 2011). In this study, (a) the theatre was used as an intervention for biodiversity education; (b) a PhD student, whose thesis is about sea turtles, wrote the script; (c) the undergraduate students, who worked the sea turtle 
conservation project as volunteers in Hatay, preformed the theatre, and (d) the context of the theatre was about marine life and conservation of the sea turtles- how people affected their nesting and next generation.

\section{Why outdoor education?}

The researchers point out the importance of outdoor education within the biodiversity education (Kilic \& Dervisoglu, 2013; Celikkol \& Soran, 2012; Kilic et al., 2012; Tankus \& Soran, 2012; Okur et al., 2011; Dervisoglu et al, 2009). Some of the properties of outdoor education are to have first-hand experience, place-based, and problem-based learning (Mitchell, 2008; Powers, 2004; Piller, 2002). The problem-based and place- based subject of the study is the conservation applications of the sea turtles on Samandag Beaches in Hatay. The scientific research are not enough to protect the sea turtles life. The rural people should also have knowledge and awareness about this subject. Hence, all groups were gone to the nesting areas on the beach after theatre performance; they observed the nesting areas, and cleaned the beach for sea turtle exit.

Why $6^{\text {th }}$ grade?

Scholars and educators especially recommend that children should be introduced to the biodiversity concept in early ages (Okur et al., 2011; Dervisoglu et al., 2009; Weels \& Zeece, 2007; Erten, 2004). The biodiversity concept is started to mention at 4th grade under the 'Science\& Technology' lesson in Turkish teaching program (MEB, 2013). Hicks and Holden (1995) also reported that environmental concern peaked at the 11- 12 years old children. Hence, we think that 6 th grade students are more available for this study because the students would have some knowledge about the biodiversity last two years and we would specifically mention the sea turtles. They also have enough maturity for understanding the theatre context and outdoor applications.

Sample group was selected one of the middle school in Samandag in 2004- 2005 education period. There were two groups; experimental and control group and the groups were selected randomly. The population of the groups was 206. 106 of them were female and 100 of them were male. There were 90 students in the experimental group, and 116 students in the control group.

\section{Knowledge test}

This research is based on the quantitative approach, and a knowledge test was developed for the study. There were 25 questions at the first version of the study. Pro-application of the test was applied another $6^{\text {th }}$ grade students and calculated discriminant and difficulty indexes of the questions (Sencan, 2005). 10 questions were thrown out according to the calculations. KR.21 value was calculated rest of the questions and found 0.71. Its mean the test was competent in order to evaluate biodiversity knowledge level of the $6^{\text {th }}$ grade students (Connolly, 2007; Sencan, 2005). The test (Appendix) questions were about marine ecology, importance of the sea turtles, usage and importance of the beaches and it's durability, and 
human effects on marine life. The test was also designed as open-ended in order to prevent to randomly selection.

\section{Program application}

This study was happened within a TUBITAK (Scientific and Technical Research Council of Turkey) project (Project no: YDABAG- 104Y055). The theatre's name was "Visitor who is coming from the sea". The experimental group only watched the theatre, and the control group had a lesson by a lecturer who was experts on sea turtles. The knowledge test was applied before the theatre and the lesson for both groups. Later, both groups were taken away to the beach for the outdoor applications. The lecturer explained how sea turtles came to the beach, made a nest, and showed the real nesting areas. All groups cleaned the beaches at this stage of the applications. The knowledge test was reapplied for both groups after the outdoor applications.

\section{Data Analysis}

Firstly, Kolmogorov- Smirnov test was used in order to decide whether the data was parametric or nonparametric. If the significant value is above than 0.05; its mean is that the data is parametric. (Daniel, 2011; Buyukozturk, 2007a; Connolly, 2007) The paired samples ttest was used in the research because we had a big sample size, the data was parametric. The scale was applied two times as pre/post-test. We also used independent samples t-test in order compare the groups' results. On the other hand, the ANCOVA (Analysis of covariance) was applied in order to control the effect of pre-test on post-test scores and in order to determine effectiveness of applied method (Buyukozturk, 2007b, p. 47). The confidence interval is chosen as 95\%. (Daniel, 2011; Buyukozturk, 2007a; Connolly, 2007). SPSS 13 was used for the analyses. The data was coded as '0- wrong answer' and '1- correct answer.'

\section{Results}

Firstly, the pre-test scores of the groups were compared and there was not any difference between groups $(p>0.05)$. Its mean was the groups' knowledge levels were close to each other. Secondly, pre/post-test scores of each group were compared. There was no difference according to the comparison of the control group ( $p>0.05$ ).

Table 1. Comparison of pre-test and post-test total scores of experimental group

\begin{tabular}{lcccccc}
\hline Experimental Group & N & Mean & SD & Df & t & p \\
\hline Pre-test & 90 & 4.74 & 2.50 & 89 & 20.630 & 0.000 \\
Post-test & 90 & 11.11 & 2.02 & & & \\
\hline
\end{tabular}

On the other hand, there was a meaningful difference according to comparison of the experimental group $(\mathrm{p}<0.05$, Table 1). The mean post-test score increased to 11.11 while the 
mean score of pre-test was 4.74 . The theatre method was successful on increasing knowledge level of students about sea turtles.

Thirdly, the post-test scores of the groups were compared and there was a meaningful difference between groups ( $p<0.005$, Table 2$)$. The mean post-test score of the control group was 4.89 while the mean post-test score of the experimental group was 11.11. The theatre method was more successful than lecturing on increasing knowledge level of students about sea turtles.

Table 2. Comparison of post-test total scores of experimental and control groups

\begin{tabular}{ccccccc}
\hline Post-test & N & Mean & SD & df & t & p \\
\hline Experimental group & 90 & 11.11 & 2.02 & 204 & 21.501 & 0.000 \\
Control group & 116 & 4.89 & 2.09 & & & \\
\hline
\end{tabular}

The ANCOVA result was presented in terms of confirmation of post-test comparison result at Table 3. It was clear that there was a meaningful difference between recovered posttest scores of groups $\left(\mathrm{F}_{[1 ; 203]}: 608.507, \mathrm{p}<.05\right.$, Table 3$)$. It has meant that the theatre method was an effective way in order to gain knowledge about sea turtles.

Table 3. ANCOVA result of post-test according to pre-test scores

\begin{tabular}{lcccccc}
\hline Source & $\begin{array}{c}\text { Type I Sum of } \\
\text { squares }\end{array}$ & df & $\begin{array}{c}\text { Mean } \\
\text { square }\end{array}$ & F & p & $\begin{array}{c}\text { Eta } \\
\text { square }\end{array}$ \\
\hline Corrected Model & 2172.581 & 2 & 1086.290 & 335.974 & 0.000 & .768 \\
Pre-test & 205.122 & 1 & 205.122 & 63.441 & 0.000 & .238 \\
Group & 1967.459 & 1 & 1967.459 & 608.507 & 0.000 & .750 \\
Error & 656.351 & 203 & 3.233 & & & \\
\hline Corrected total & 2828.932 & 205 & & & & \\
\hline
\end{tabular}

The corrected post-test mean of experimental group was 11.12 while the corrected post-test mean of control group was 4.88 . It has meant that the experimental group was more successful than control group in terms of gaining knowledge. On the other hand in terms of eta square, being in different groups explained $75 \%$ of variability of post-test scores while the pre-test scores explained $23 \%$ of variability of groups' post-test scores $\left(\mathrm{F}_{[1 ; 203]}: 63.441, \mathrm{p}<.05\right.$, Table 3). Both group and pre-test together explained $76 \%$ of variability of groups' post-test scores; in other words ANCOVA model was correct $\left(\mathrm{F}_{[1 ; 203]}\right.$ : $335.974, \mathrm{p}<.05$, Table 3$)$. 


\section{Discussion}

We reached two results within this study: (1) The theatre method is effective in order to gain knowledge about sea turtles; (2) the theatre method is more successful than lecturing on increasing knowledge level of students about sea turtles (Table 1, 2, 3). Peleg and BaramTsabari (2011), Nwadigwe (2007), and Elliott et al. (1996) pointed out the same result; the theatre method is an effective way in order to get knowledge.

The children were the audiences in this study. However, the students can also write a script related to the sea turtles or the other subjects. The students were in the writing and performance processes in Barker and Elliott's (2000) research. They determined increasing knowledge level of the students, as well. Being in the writing or performance process might be effective to develop varied skills. Within this perspective, media may also be used in order to support the biodiversity education. In rural areas, a radio is a principal tool for informal education and every house has a TV. The theatres related to local environmental problems may be performed on a local TV or radio (as radio theatre). These documents can be recorded and used as an education tool for the local schools in order to gain knowledge.

The knowledge belongs to cognitive learning area. Barry (2010) also said that affective learning should be developed in order to understand complex environmental subjects. Hence, this research may be repeated within environmental sensitivity, attitude, awareness, environmental behavioural changing, gaining holistic perspective etc.

The researchers say that the theatre method is also effective on self-reflection, analytical, and critical thinking (Rudman, 1972; Hopkins 1963; Lippman, 1951). Agenda 21 (UN, 1992) also suggests the cooperation between NGOs and the other governmental institutions. Wondolleck and Yaffee (2000) described 'collaborative approach' as a sense of shared ownership and responsibility for the natural resources. There are professional and amateur theatre groups in Turkey. The schools can collaborate with these groups and the theatre may also be used for the other disciplines. On the other hand, this research was based on the quantitative approach, and only limited by knowledge acquisition. Different theatre scripts or assessment methods may be used according to the research aims in further research. For instance Peleg and Baram- Tsabari (2011), and Nwadigwe (2007) used mixed methodology and it helped to evaluate the results more deeply. The children should have critical and analytical thinking abilities about the biodiversity and human effects on the natural environment because the biodiversity is an interdisciplinary subject (Sarabhai, 2011; Dervisoglu, Menzel, Soran, \& Bogeholz, 2009; Dervisoglu, 2007; Barker \& Elliot, 2000; Agenda 21, UN, 1992). In next grades and ages, the children would have more knowledge about different disciplines so they should contact among them. In further researches may focus on development of critical and analytical thinking. The students in older ages or next grades might be more interested in their living area because most of the local/ rural inhabitants cannot know the importance of their living area. One of the problems of the marine conservation is the lack of the public's contact with marine habitats. The habitat and species are not valued if they aren't known (Kassas, 2002b). Hence, the biodiversity education is obviously needed in order to ensure responsibility towards real environmental improvement 
and widely recognized as being crucial for achieving long-term conservation (Young, 2001). Smyth (1995) reported that the education programmes should encourage people not only to learn but also to take ownership of their learning, and help people to relate between local action and global issues. Gaining knowledge might be evaluated the first step of the local action. We found that students gained knowledge about sea turtles but we do not know whether they will have local action in order to protect sea turtles and their habitats. In further research, different education programs/courses might be developed and the students might be followed up in long terms.

There is not any specific environment/ ecology/ sustainability / biodiversity lesson/ course in the primary and secondary schools in Turkey. The environmental subjects are under the science and technology or biology lessons. 'Environment' course is only at some departments within the tertiary level but it is not enough for Turkey because Turkey is one of the 34 global hot points on the world and have to protect many more biodiversity (Kilic \& Dervisoglu, 2013; Kilic, Dervisoglu, \& Kasap, 2012; Okur, Yalcin-Ozdilek, \& Sahin, 2011; Sarabhai, 2011; Uzun, Ozsoy, \& Keles, 2010; Dervisoglu et al, 2009; Dervisoglu, 2007; Erten, 2004). According to Agenda 21 (UN, 1992), all age levels are needed to education for environmental subjects. Environment/ Ecology/ Sustainable Development course should be a compulsory lesson for each educational level and for each department - especially for teacher education department- at the tertiary level in Turkey. A biodiversity course should also be opened as a compulsory/ an optional course. All these courses should be managed varied active learning methods and outdoor educations. Firstly a teacher should know the environmental concepts, their relationship, how to teach them and later s/he can teach own acquisitions. This helps to improve self-confidence and competency of the teachers (Kilic \& Dervisoglu, 2013; Lindemann et al., 2011; Lindemann et al., 2009; Gayford, 2000).

TUBITAK has financed the outdoor environmental education projects intended for teachers since 1999 (Erentay \& Erdogan, 2009). There are also outdoor education projects intended for the students- even preschool students, recently (TUBITAK, $2010 \& 2011$ ). These projects are carried out within collaboration with the universities. The aims of the TUBITAK from the projects is to teach environmental subjects via outdoor experimental applications, an actual language, to gain environmental awareness, attitudes, behavioural changing, and to have active role for the solutions of the environmental problems (TUBITAK Invitation Paper, 2013). Barker and Elliott (2000), and Dervisoglu et al. (2009) expressed the biodiversity education should be started as young as possible. It is a good and hopeful development for Turkey but these projects are very expensive and the participant numbers are limited so Turkey should support the institutionalization.

A school is an institution and the indoor or outdoor activities can be done within school. There are also outdoor environmental education institutions or centres. A zoo, science museum, or an aquarium may be used within outdoor environmental/ biodiversity education (Bozdogan, 2007; Tsai, 2006; Ford, 1986). In Turkey, there are outdoor education centres at the limited level. Last decade, TUBITAK has started to support opening more outdoor education centres (Bursa Science Museum, 2013; TUBITAK Legislation, 2012) but then again, there is still shortage about 'outdoor environmental education centres'. The outdoor 
environmental education centres are at the institutionalization level in Australia and New Zealand (Auckland City Council, Waikato Environmental Trust, Canterbury Environmental Trust, etc.) and there are many centres. There is also a specific department about the sustainability and outdoor education at the Canterbury Polytechnic Institute of Technology (CPIT, 2013). The universities in New Zealand support the sustainability via different applications. For example the University of Otago and University of Waikato are very successful about sustainability applications and they have 'sustainability action plans' (The University of Otago, 2013; The University of Waikato, 2010). As a result, the teachers, students, academicians, and public can easily have environmental/ biodiversity education and sustainability applications. These institutions are good samples for the sustainable development of Turkey.

This research is place-based and based on sea turtles C. mydas and C.caretta. The sea turtles are one of the biological richness of Turkey. We would like to take attention biodiversity education in Turkey via this research. Different endemic or endangered species in different habitats might be used for biodiversity education. C. mydas and C.caretta are also endangered species and they need the conservation. The recent conservation studies in Samandag beaches are mostly related to biological properties of the sea turtles (YalcinOzdilek \& Sonmez, 2006). It is suggested that Samandag beach must have been announced as 'Protected Area'. According to IUCN, a protected area is defined as "an area of land/sea especially dedicated to the protection and maintenance of biological diversity and of natural and associated cultural resources, and managed through legal or other effective means" (IUCN, 1994: 8). This area has to be protected from human stress and it is needed educational programs especially for Samandag inhabitants.

Natural environment is not something to be controlled, exploited, conquered or worshipped (Barry, 2010). Maybe we should change our perspective instead of the changing/ stressing the natural environment, and its unique members.

\section{Acknowledgments}

We would like to show our appreciation the members of TUBITAK's project (project no. YDABAG- 104Y055), and volunteer undergraduate students.

\section{References}

Anthworth, R.L., Pike D.A., \& Siner, J.C. (2006). Nesting ecology, current status and conservation sea turtles on an uninhabited beach in Florida. Biological Conservation, 130, 10-15.

Barker, S. \& Elliott, P. (2000). Planning a skill-based resource for biodiversity education. Journal of Biology $\begin{array}{llllll}\text { Education, } & 34 & (3), & 123- & 127 . & \text { Retrieved }\end{array}$ http://web.ebscohost.com.ezproxy.waikato.ac.nz/ehost/pdfviewer/pdfviewer?sid=c3e8499b-f6b7-4638a78b-ce5b52dc56ba\%40sessionmgr112\&vid=2\&hid=125

Barry, C. (2010). The environment/ society disconnect: An overview of a concept tetrad of environment. The Journal of Environmental Education, 41 (2), 116- 132. Doi: 10.1080/00958960903295241. 
Baskent, E. Z., Kose, S., Terzioglu, S., Baskaya, S. \& Altun, L. (2005). The complete the biodiversity with the forest amenajman: The reflection of 'GEF' projects. Retrieved from http://www.orman.ktu.edu.tr/om/abds/oamenajmani/downloads/amenajman/eserler/bc tasarim.pdf

Bjorndal, K. A., Carr, A., Meylan, A. B., \& Mortimer, J. A. (1985). Reproductive biology of the hawksbill, Eretmochelys imbricata, at Tortuguero, Costa Rica, with notes on the ecology of the species in the Caribbean. Biological Conservation, 34, 353-368.

Bozdogan, A. E. (2007). The importance and place of science and technology museums in science education (Unpublished PhD Thesis), Gazi University Educational Science Institution, Ankara, Turkey.

Broderick A.C., \& Godley B.J. (1996). Population and nesting ecology of the green turtle, Chelonia mydas, and the loggerhead turtle, Caretta caretta, in northern Cyprus. Zoology in the Middle East, 13, 27-46.

Bursa Science Museum (2013). Retrieved from http://www.tubitak.gov.tr/tr/haber/tubitaktan-bursa-bilimmerkezine-40-milyon-tl

Buyukozturk, S. (2007a). Data anlaysis handbook for social science. Ankara, Turkey: Pegem A Publication.

Buyukozturk, S. (2007b). Experimental designs: Designs and data analyses of pretest/posttest/control groups. Ankara, Turkey: Pegem A Publication.

Campbell, C.L., Lagueux, C.J., \& Mortimer, J.A. (1996). Leatherback turtle, Dermochelys coriacea, nesting at Tortuguero, Costa Rica, in 1995. Chelonian Conservation and Biology, 2, 169-172.

Canbolat A.F. (1996). Examining of sea turtle (Caretta caretta (Linnaeus, 1758) population in Dalyan and Patara. (Unpublished PhD thesis) Natural Science Institution, Hacettepe University, Ankara.

Canbolat A.F. (2004). A review of sea turtle nesting activity along the Mediterranean Coast of Turkey. Biological Conservation, 116, 81-91.

Canterbury Polythechnic Institute of Technology (CPIT) (2013). Department of sustainability and outdoor education. Retrieved from http://www.cpit.ac.nz/study-options/our-study-interest-areas/sustainabilityand-outdoor-education

Carr, A., \& Carr, M.H. (1972). Site fixity in the Caribbean green turtle. Ecology, 53, 425-429.

Ceken, R. , \& Ayas, S. (2010). Revision of the elementary science and technology curricula based on the geographical conditions of the local school district. Education Journal of Erzincan University, 12 (2), 191- 207. Retrieved from http://eefdergi.erzincan.edu.tr/index.php/EFDERGI/article/viewFile/631/516

Celikkol, N. Z., \& Soran, H. (2012). The biodiversity knowledge and attitudes of secondary school students. $X$. National Science and Mathematics Conference, 27- 30 June 2012, Nigde, Turkey. Retrieved from http://kongre.nigde.edu.tr/xufbmek/dosyalar/tam_metin/pdf/2454-30_05_2012-21_15_38.pdf

Cepel, N. (2008). Ecological problems and solutions (3rd Press) Ankara: TUBITAK Popular Books Series.

Connolly, P. (2007). Quantitative data analysis in education: A critical introduction using SPSS. New York: Routledge.

Daniel, M. (2011). Doing quantitative research in education with SPSS. Los Angeles: Sage Publications.

Dervisoglu, S. (2007). Learning Pre-Conditions for Protecting the Biodiversity. Unpublished PhD Thesis. Hacettepe University, Science Institute, Ankara, Turkey.

Dervisoglu, S. Menzel, S., Soran, H., \& Bogeholz, S. (2009). Influence of values, beliefs and problem perception on personal norms for biodiversity protection. Hacettepe University Journal of Education, 37, 50-59. Retrieved

from http://www.efdergi.hacettepe.edu.tr/200937SEV\%C4\%B0LAY\%20DERV\%C4\%B0\%C5\%9EO\%C4\%9 ELU.pdf

Ehrhart L.M., \& Raymond P.W. (1983). Loggerhead (Caretta caretta) and green turtles (Chelonia mydas) nesting densities on a major east-central Florida nesting beach. Am. Zool. 23, 963 (Abstract.).

Elliott, L., Gruer, L., Farrow, K., Henderson, A. \& Cowan, L. (1996). Theatre in AIDS education-a controlled study. AIDS Care: Psychological and Socio-medical Aspects of AIDS/HIV, 8(3), 321-340. Retrieved from http://www.tandfonline.com.ezproxy.waikato.ac.nz/doi/pdf/10.1080/09540129650125740

Endangered Species of Act (ESA) (2013). 40 years of conserving endangered species. January, 2013. Retrieved from http://www.fws.gov/endangered/esa-library/pdf/ESA_basics.pdf

Erentay, N., \& Erdogan, M. (2009). Nature education at 22 steps. Ankara: METU Publication.

Ergene, S., Aymak, C., \& Uçar A. H. (2005). Nesting activity of the marine turtles (Chelonia mydas and Caretta caretta) during 2005 in Alata, Mersin-Turkey. $26^{\text {th }}$ Sea Turtle Symposium. 3-8 April 2006 Crete, Greece (2005), pp: 293. 
Erten, S. (2004). Biodiversity as a rising value in the international scale. The Journal of Hacettepe University, Faculty of Education, 27, 98-105. Retrieved http://www.efdergi.hacettepe.edu.tr/200427SINAN\%20ERTEN.pdf

Ford, P. (1986).Outdoor education: Definition and philosophy. ERIC Publications; ERIC Digests in Full Text ERIC Clearinghouse. Retrieved from http://www.eric.ed.gov/PDFS/ED267941.pdf

Gayford, C. (2000). Biodiversity education: A teacher's perspective. Environmental Education Research, 6 (4), 347- 361. doi: 10.1080/713664696. from http://web.ebscohost.com.ezproxy.waikato.ac.nz/ehost/pdfviewer/pdfviewer?sid=20c0164e-3322-42b5aa90-51f235e817aa\%40sessionmgr112\&vid=2\&hid=125

Hawkey (2001). Walking with woodlice: An experiment in biodiversity education. Journal of Biological $\begin{array}{lllll}\text { Education. } & 36 & \text { (1), } & \text { Retrieved } & \text { from }\end{array}$ http://web.ebscohost.com.ezproxy.waikato.ac.nz/ehost/pdfviewer/pdfviewer?sid=915b5e89-94c6-49ea83d3-38288ab9b52b\%40sessionmgr110\&vid=2\&hid=125

Hicks D. \& Holden C. (1995). Exploring the future: a missing dimension in environmental education. Environmental Education Research, 3 (2), 189- 201.

Hilton-Taylor, C. (2000). 2000 IUCN Red List of Threatened Species. Cambridge, UK: IUCN Publication.

Hopkins, H. (1963). Education by theatre. Educational Theatre Journal, 15 (4), 299-310. Retrieved from http://www.jstor.org.ezproxy.waikato.ac.nz/stable/pdfplus/3204847.pdf?acceptTC=true

Ilgaz C. (1998). An investigation on marine turtles population of Northern Karpaz and Dalyan beaches and the effect of different ecological conditions on hatching success. (Unpubliahed MSc Thesis), Dokuz Eylül University.

IUCN (1994). Guidelines for Protected areas Management Categories. IUCN Commision on National Parks and Protected Areas with the assistance of the World Conservation Monitoring Centre, Gland, Switzerland. Retrieved from http://data.iucn.org/dbtw-wpd/edocs/paps-016.pdf

Kaska Y. (1998). Studies on the embryology, ecology and evolution of sea turtles in the eastern Mediterranean. (Unpublished PhD Thesis), University of Glasgow.

Kassas, M. (2002a). Biodiversity: gaps in knowledge. The Environmentalist, 22, 345-351. Retrieved from http://link.springer.com.ezproxy.waikato.ac.nz/content/pdf/10.1023\%2FA\%3A1020766914456.pdf

Kassas, M. (2002b). Environmental education: Biodiversity. The Environmentalist, 22, 43-49. Retrieved from http://kassas.org/wp-content/uploads/2013/03/067.pdf

Kilic, D. S., Dervisoglu, S., \& Kasap, M. Y. (2012). The effect of youth's personal and group efficacy beliefs on their commitment to protect species. Journal of Research in Education and Teaching, 1 (2), $289-294$. Retrieved from http://jret.org/FileUpload/ks281142/File/33. kilic.pdf

Kilic, D. S., \& Dervisoglu, S. (2013). Teacher candidates' pedagogical content knowledge, attitudes and concerns regarding teaching biodiversity. Journal of Research in Education and Teaching, 2 (1), 100109. Retrieved from http://www.jret.org/FileUpload/ks281142/File/11a.dilek_sultan_kilic.pdf

Lindemann-Matthies, P., Constantinou, C., Lehnert, H. J., Nagel, U., Raper, G., \& Kadji-Beltran, C. (2011). Confidence and perceived competence of preservice teachers to Implement biodiversity education in primary schools - four comparative case studies from Europe. International Journal of Science Education, 33 (16), 2247-2273. doi: http://dx.doi.org/10.1080/09500693.2010.547534

Lindemann-Matthies, P., Constantinou, C., Junge, X., Kohler, K., Mayer, J., Nagel, U., Raper, G., Schule, D., \& Kadji-Beltran, C. (2009). The integration of biodiversity education in the initial education of primary school teachers: four comparative case studies from Europe. Environmental Education Research, 15 (1), 17-37. Retrieved from

http://web.ebscohost.com.ezproxy.waikato.ac.nz/ehost/pdfviewer/pdfviewer?sid=517be9ff-3d11-4212af1c-40362744f991\%40sessionmgr113\&vid=2\&hid=125

Lippman, M. (1951). Education and a free theatre. Educational Theatre Journal, 3 (2), 95-98. Retrieved from http://www.jstor.org.ezproxy.waikato.ac.nz/stable/pdfplus/3203934.pdf

Marcovaldi M.A., \& Laurent, A.(1996). A six season study of marine turtle nesting at Praia do Forte, Bahia, Brazil, with implications for conservation and management, Chelonian Conservation and Biology, 2, 5559. 
MEB (National Education Ministry of Turkey) (2013). Retrieved from http://ttkb.meb.gov.tr/www/ogretimprogramlari/icerik/72

Menzel, S., \& Bogeholz, S. (2010). Values, beliefs and norms that foster Chilean and German pupils' commitment to protect biodiversity. International Journal of Environmental \& Science Education, 5 (1), 31- 49. Retrieved from

http://web.ebscohost.com.ezproxy.waikato.ac.nz/ehost/pdfviewer/pdfviewer?sid=6a8e711e-30f0-480cb689-593752cb1d2e\%40sessionmgr114\&vid=2\&hid=125

Mitchell, W. (2008). The changing climate of outdoor education in the Quebec Cegep System. (Unpublished master thesis) Faculty Of Education Lakehead Unıversity, Ontario, Canada.

Nwadigwe, C. E. (2007). 'Meet us at the other side of the river': performance venue and community education among migrant fishermen in Nigeria. Research in Drama Education: The Journal of Applied Theatre and Performance, 12 (1), 65-77. doi: http://dx.doi.org/10.1080/13569780601095006

O'Farrell, L. (2002). Theatre-in-education: expanding the parameters. TRiC / RTaC , 23 (1-2), 119-129. Retrieved

from

http://web.ebscohost.com.ezproxy.waikato.ac.nz/ehost/pdfviewer/pdfviewer?sid=85e2bd49-81b7-49cb969b-9cbfb4a0df4e\%40sessionmgr104\&vid=2\&hid=112

Okur, E., Yalcin-Ozdilek, S., \& Sahin, C. (2011). The common methods used in biodiversity education by primary school teachers (Canakkale, Turkey). Journal of Theory and Practice in Education, 7 (1), 142159. Retrieved from http://eku.comu.edu.tr/index/7/1/eokur_syozdilek_csahin.pdf

Peleg, R. \& Baram-Tsabari, A. (2011). Atom surprise: using theatre in primary science education. Journal of Science Education and Technology, 20, 508-524. doi: 10.1007/s10956-011-9299-y

Piller, N. (2002). Outdoor education: A dialogue between theory and practice, and implementation suggestions for the Discovery 10 Program at St. George's School. (Published master of arts thesis) The University of British Columbia, The Faculty of Education Department of Curriculum Studies, Canada. Retrieved from https://dspace.library.ubc.ca/bitstream/handle/2429/13379/ubc_20020534.pdf?sequence=1

Powers, D. L. (2004). The effects of an outdoor education program on life effectiveness skills of participants. (Unpublished master of science thesis) California State University, California, USA.

Rosenberg, H. (1973). Theatre in education: The Belgrade Team. The Elementary School Journal, 74, (2), 8487. Retrieved from http://www.jstor.org.ezproxy.waikato.ac.nz/stable/pdfplus/1000710.pdf

Rudman. M. (1972). "The Learning Theatre": Education for A.D. 2000. Improving College and University Teaching, 20 (4), Classroom: Learning Center, 297-298 Retrieved from http://www.jstor.org.ezproxy.waikato.ac.nz/stable/pdfplus/27563436.pdf

Saito, C. H. (2013). Environmental education and biodiversity concern: beyond the ecological literacy. American Journal of Agricultural and Biological Sciences, $8 \quad$ (1), 12-27. http://scholar.google.com/scholar?q=\%22ENVIRONMENTAL+EDUCATION+AND+BIODIVERSITY + CONCERN\%3A+BEYOND+THE+ECOLOGICAL+LITERACY\%22\&btnG=\&hl=tr\&as_sdt=0\%2C5

SANZ (Sustainable Aotearoa New Zealand INC) (2009). Strong Sustainability for New Zealand: Principles and Scenarios, Auckland, New Zealand: Nakedize Limited Publication.

Sarabhai, K. V. (2011). Biodiversity and ESD. Journal of Education for Sustainable Development , 5 (2), 159161. Retrieved from http://jsd.sagepub.com.ezproxy.waikato.ac.nz/content/5/2/159

Sencan, H. (2005). Reliability and validity in social and behavioral measures. Ankara: Seckin Publication.

Sextou, P. (2006). A theatre-in-education study of multicultural understanding in hellas. Youth

Theatre Journal, 20 (1), 77-93. doi: http://dx.doi.org/10.1080/08929092.2006.10012588

Smyth J. C., 1995. Scotland: Developing a national strategy for environmental education. pp. 111- 119.

Souto- Manning, M. (2011). Playing with power and privilege: Theatre games in teacher education. Teaching and Teacher Education, $27 \quad$ (2011) 997-1007. Retrieved from http://dx.doi.org.ezproxy.waikato.ac.nz/10.1016/j.tate.2011.04.005

Tankus, M., \& Soran, H. (2012). The examining of the perception, belief, and behaviour tendency of secondary school students toward the wetland protection. X. National Science and Mathematics Conference, 27- 30 June 2012, Nigde, $\quad$ Turkey. Retrieved from http://kongre.nigde.edu.tr/xufbmek/dosyalar/tam_metin/pdf/2377-30_05_2012-14_55_21.pdf

The University of Otago (2013). Retrieved from http://www.csafe.org.nz/ 
The University of Waikato (2010). Leading the way to a sustainable future. Retrieved from http://www.waikato.ac.nz/research/ResearchReport.pdf

Tsai, J. T. (2006). The identification of the components for an outdoor education curriculum in Taiwan. (Unpublished $\mathrm{PhD}$ thesis) The School of Health, Physical Education and Recreation Indiana University, USA.

TUBITAK (2010). Department of Science- Society Department, 4004 coded projects. Retrieved from http://www.tubitak.gov.tr/tubitak content_files//bilimtoplum/dogaegitimi/6994_websiteleri_bilisim.pdf

TUBITAK (2011). Department of Science- Society Department, 4004 coded projects. Retrieved from http://www.tubitak.gov.tr/tubitak_content_files//bilimtoplum/dogaegitimi/Liste_iletisim_14062011.pdf

$\begin{array}{llll}\text { TUBITAK } & \text { Legislation } & \text { (2012). } & \text { from }\end{array}$ http://www.tubitak.gov.tr/sites/default/files/yonetmelik_iii_4_0.pdf

$\begin{array}{lllll}\text { TUBITAK Invitation } & \text { Paper } & \text { Retrieved } & \text { from }\end{array}$ http://www.tubitak.gov.tr/sites/default/files/4004_cagri_metni_1.pdf

UN (United Nations) (2001). Compendium of Human Settlements Statistics 2001. Retrieved from http://unstats.un.org/unsd/demographic/sconcerns/housing/publications/Series_N6.pdf

UN (United Nations) (1992). United Nations Conference on Environment \& Development Rio de Janerio, Agenda 21. Retrieved from http://sustainabledevelopment.un.org/content/documents/Agenda21.pdf

UN (United Nations) (2009). Investment policy developments in G-20 countries. Retrieved from http://unctad.org/en/Docs/webdiaeia20099 en.pdf

Uzun, N., Ozsoy, S., \& Keles, O. (2010). Pre-service teachers' views about the concept of biodiversity. The Research Journal of Biology Science (Biyoloji Bilimleri Araştırma Dergisi) 3 (1), 85-91. Retrieved from http://nobel.gen.tr/Makaleler/B\%C4\%B0BAD-Issue\%201-40-2011.pdf

Weishampel J.F., Bagley, D.A., Ehrhart L.M., \& Rodenbeck L.B. (2003). Spatiotemporal patterns of annual sea turtle nesting behaviours along an East Central Florida beach. Biological Conservation, 110, 295-303.

Weels R., \& Zeece P. D. (2007). My place in my world: literature for place- based environmental education. Early Childhood Education Journal, 35 (3), 285- 291.

Wondolleck J. M., \&Yaffee S. L. (2000). Making collaborative work: Lessons from innovation in natural resource management. Washington DC: Island Press.

Yalcin- Ozdilek, S., \& Sönmez B. (2006). Some properties of new nesting areas of sea turtles in northeastern Mediterranean situated on the extension of the Samandag Beach, Turkey. Journal of Environmental Biology, 27 (3), 537-544.

Young J. (2001). Linking Efs (Education for Sustainability) and Biodiversity? A UK-wide survey of the status of education within local biodiversity action plans. Environmental Education Research, 7 (4), 439- 444. 


\section{Appendix}

\section{Knowledge Test Questions}

Please replay questions shortly on the empty spaces where they are under the questions. If you don't know, you may write nothing or write that you don't know.

1. How many sea turtles are there you know?

2. What is the sea turtles usefulness to the nature?

3. Where do the sea turtles live and why do they come to the beach?

4. How many times do the sea turtles' lay eggs until completing their growth?

5. How can a baby sea turtle find own way in the sea?

6. How does the light, which comes from land, affect the baby sea turtles?

7. Who are native enemies of the baby sea turtles?

8. Why cannot we bring the sea turtles to our house?

9. How do the fishing techniques, which perform near the beach, affect the sea turtles?

10. How does the garbage at beach affect the baby sea turtles?

11. What do the sea turtles eat?

12. What is the origin of the sand?

13. If the sand is taken continuously from the beach, what happened?

14. What is the usefulness of the beach sand?

15 . Why don't we excavate the beach? 